\title{
Tinjauan Islam terhadap Mekanisme Pasar dan Penanganan Distorsinya
}

\author{
Cahya Wulandari \\ Universitas Pembangunan Nasional Veteran Jakarta \\ Koiriyah Azzahra Zulqah \\ Universitas Pembangunan Nasional Veteran Jakarta
}

Received: August 6, 2020 | Accepted: August 8, 2020 | Published: August 11, 2020

\begin{abstract}
The market which is a meeting between supply and demand must take place fairly. Islam prohibits actions that can tyrannize and harm others. This article aims to examine Islamic principles that must be applied in the market mechanism so that a healthy and fair market can occur, as well as provide benefits for all parties. Apart from that, this study will also analyze the prohibited actions that can distort the market. The study is written using a descriptive qualitative approach, describing various theories from several kinds of literature. This study underlines that the market in the Islamic economic system must maintain the values of honesty and justice. Besides, the parties involved in the market should avoid practices that can damage the market mechanism, thus causing harm to others. Some forms of actions prohibited by Islam in the market mechanism include intikar or hoarding of goods to raise the price of goods on the market, bai najasy which is a prohibited trading practice, taghrir in the form of unclear prices or quality and quantity of goods traded, and tadlis which constitute fraudulent practices. This study recommends that the Government establish provisions so that markets that take place in a society run fairly without any disadvantaged parties.
\end{abstract}

Keywords: Market; Mechanism; Distortion

\begin{abstract}
Abstrak
Pasar yang merupakan pertemuan antara permintaan dan penawaran harus berlangsung secara adil. Islam melarang tindakan-tindakan yang dapat menzalimi dan merugikan orang lain. Artikel ini bertujuan untuk mengkaji prinsip-prinsip Islam yang harus diterapkan dalam mekanisme pasar, sehingga terjadi pasar yang sehat dan adil, serta memberikan maslahat bagi semua pihak. Selain itu, kajian ini juga akan menganalisis tindakan-tindakan terlarang yang dapat mendistorsi pasar. Kajian ditulis dengan pendekatan kualitatif deskriptif, dengan menjabarkan berbagai teori dari beberapa literatur. Kajian ini menggarisbawahi bahwa pasar dalam sistem Ekonomi Islam harus menjaga nilai-nilai kejujuran dan keadilan. Selain itu, pihak-pihak yang terlibat di dalam pasar agar menghindari praktik-praktik yang dapat merusak mekanisme pasar, sehingga merugikan orang lain. Beberapa bentuk tindakan yang dilarang Islam dalam mekanisme pasar antara lain ihtikar atau penimbunan barang untuk menaikkan harga barang di pasar, bai najasy yang merupakan praktik jual beli terlarang, taghrir dalam bentuk ketidakjelasan harga ataupun kualitas dan kuantitas barang yang diperdagangkan, dan tadlis yang merupakan praktik penipuan. Kajian ini merekomendasikan agar Pemerintah menetapkan ketentuan-ketentuan agar pasar yang berlangsung di masyarakat berjalan secara adil tanpa adanya pihak yang dirugikan.
\end{abstract}

Kata kunci: Pasar; Mekanisme; Distorsi 


\section{PENDAHULUAN}

Pasar secara umum adalah sarana atau tempat bertemunya penjual dengan pembeli, baik itu secara langsung maupun tidak langsung, guna melakukan aktivitas transaksi jual beli. Pasar memiliki fungsi yang penting dalam perekonomian suatu negara meskipun sering terjadi kecurangan dan ketidakadilan di dalam pasar terutama masalah harga. Oleh karena itu terdapat sejumlah aturan tentang pembentukan harga dan transaksi yang terjadi di pasar. Aturan tersebut sering kita namakan dengan mekanisme pasar yaitu proses penentuan harga berdasarkan dari kekuatan permintaan dan penawaran. Mekanisme pasar merupakan suatu sistem yang cukup efisien dalam mengalokasikan berbagai faktor produksi dan mengembangkan perekonomian, tetapi dalam keadaan tertentu dapat menimbulkan akibat yang buruk, sehingga dibutuhkan campur tangan dari pemerintah untuk memperbaikinya.

Tidak jauh beda dengan pasar menurut pandangan umum, Pasar dalam pandangan islam pun memiliki konsep tersendiri, yaitu konsep syariah yang terdiri atas tiga hal yang mendasar yaitu keadilan, menghindari segala bentuk aktifitas yang dilarang dan memperhatikan aspek kemanfaatan. Ketiga prinsip tersebut menciptakan sistem ekonomi yang seimbang yaitu keseimbangan antara memaksimalkan keuntungan dengan pemenuhan prinsip syariah yang menjadi hal mendasar dalam kegiatan pasar. Adapun dalam hal mekanisme pasar, ekonomi islam juga memiliki konsep tersendiri yang mencerminkan prinsip syariah dalam bentuk nilai-nilai yang secara umum dapat dibagi dalam dua perspektif yaitu makro dan mikro. Peranan ekonomi Islam dalam mekanisme pasar juga dinilai sangat penting karena ekonomi Islam dapat menyumbang peran yang besar di tengah ketidakstabilan kondisi perekonomian bangsa indonesia saat ini.

Ekonomi Islam memandang bahwa pasar, negara, dan individu berada dalam keseimbangan. Pasar dijamin kebebasannya dalam Islam. Pasar bebas menentukan cara-cara produksi dan harga, tidak boleh ada gangguan yang mengakibatkan rusaknya keseimbangan pasar. Dalam Konsep Ekonomi Islam penentuan harga dilakukan oleh kekuatan-kekuatan pasar, yaitu kekuatan permintaan dan penawaran. Pertemuan antara permintaan dan penawaran tersebut harus terjadi rela sama rela, sehingga tidak ada pihak yang merasa terpaksa, tertipu ataupun adanya kekeliruan dalam melakukan transaksi barang tertentu pada tingkat harga tertentu sehingga tidak ada pihak yang merasa dirugikan. Dengan demikian, Islam menjamin pasar bebas dimana para pembeli dan penjual bersaing satu sama lain dengan arus informasi yang berjalan lancar dalam kerangka keadilan. Namun keadaan pasar yang ideal menurut prinsip Islam tersebut, tidaklah sesuai dengan keadaan yang sebenarnya dilapangan, karena seringkali adanya gangguan yang terjaadi terhadap mekanisme pasar ini. Dan 
gangguan-gangguan inilah yang disebut dengan Distorsi Pasar atau ketidakseimbangan pasar.

Pada era digital saat ini, mekanisme pasar di harapkan akan terus berlangsung dengan sistem keadilan bagi seluruh umat manusia, terlebih lagi dalam hal penentuan harga. Peran pemerintah pun sangat di perlukan disini untuk mengawasi jalannya ekonomi pasar yang adil, jujur dan sehat, dalam artian tidak adanya transaksi yang dilarang didalam nya.

Artikel mengkaji serta menganalisis pola mekanisme pasar yang terjadi dengan menjalankan prinsip-prinsip Islami. Selain itu analisis juga dilakukan terhadap berbagai bentuk tindakan terlarang yang umumnya terjadi di pasar. Dengan demikian, diharapkan Pemerintah dapat menetapkan ketentuanketentuan dalam rangka meminimalisir terjadinya praktik kecurangan ataupun penipuan yang dapat merugikan pihak lainnya, sehingga dapat terbangun pasar yang berlangsung dengan asas kejujuran dan keadilan.

\section{TINJAUAN PUSTAKA}

\section{A. Konsep Pasar dan Mekanismenya}

Pasar dalam pengertian ilmu ekonomi adalah pertemuan antara permintaan dan penawaran. Pasar bersifat interaktif. Adapun mekanisme pasar adalah proses penentuan tingkat harga berdasarkan kekuatan permintaan dan penawaran. Pertemuan antara permintaan (demand) dan penawaran (supply) dinamakan equilibrium price (harga keseimbangan) (Rahardja \& Manurung, 1999).

Pasar merupakan tulang punggung perekonomian masyarakat, baik masyarakat yang berada dikalangan ataupun masyarakat kelas atas. Semua unsur yang berkaitan dengan hal ekonomi berada dipasar, mulai dari unsur produksi, distribusi, ataupun unsur konsumsi. Aktivitas yang dilakukan di pasar pada dasarnya akan melibatkan produsen dan konsumen masing masing dari mereka mempunyai peranan yang sangat penting terhadap pembentukan harga dalam pasar (Ekomadani, 2015).

Pasar merupakan tempat atau keadaan yang mempertemukan antara permintaan (pembeli) atau penawaran (penjual) untuk melakukan transaksi jual beli barang dan jasa. Sehingga akhirnya dapat menetapkan harga keseimbangan (harga pasar) dan jumlah yang diperdagangkan. Jadi setiap proses yang mempertemukan antara penbeli dan penjual, maka akan membentuk harga yang disepakati antara penjual dan pembeli .

Dalam teori ekonomi konvensional, mekanisme pasar adalah suatu cara agar dapat mencapai tujuan ekonomi, yakni berupa kesejahteraan masyarakat di dunia, dan kesejahteraan masyarakat itu didefinisikan sebagai kesejahteraan material. Dengan kata lain kualitas kehidupan manusia itu tidak hanya ditentukan oleh 
kemampuan untuk memenuhi kesejahteraan material saja tapi juga untuk memenuhi kesejahteraan non-material.

Mekanisme pasar dalam perspektif islam tentunya mengandung prinsip syariah dalam bentuk nilai-nilai yang secara umum menekankan pada konsep maslahat yaitu yang menjunjung tinggi asas-asas keadilan, etika dan norma hukum dalam kegiatan ekonomi. Prinsip-prinsip syariah juga dapat dibagi dalam dua perspektif yaitu makro dan mikro. Nilai syariah dalam prespektif mikro menekankan aspek kompetensi/ profesionalisme dan sikap amanah, sedangkan dalam prespektif makro nilai-nilai syariah menekankan aspek distribusi, pelarangan riba dan kegiatan ekonomi yang tidak memberikan manfaat secara nyata kepada sistem perekonomian. Oleh karena itu, manfaat sistem perekonomian Islam dalam pasar ditujukan tidak hanya kepada umat Islam, melainkan kepada seluruh umat manusia.

Pentingnya pasar sebagai wadah aktifitas tempat jual beli tidak hanya dilihat dari fungsinya secara fisik, namun aturan, norma dan yang terkait dengan masalah pasar. Dengan fungsi di atas, pasar jadi rentan dengan sejumlah kecurangan dan juga perbuatan ketidakadilan yang menzalimi pihak lain. Karena peran penting pasar dan juga rentan dengan dengan hal-hal yang dzalim, maka pasar tidak terlepas dengan sejumlah aturan syariat. Dalam istilah ini dapat disebut sebagai mekanisme pasar menurut Islam dan intervensi pemerintah dalam pengendalian harga. Konsep mekanisme pasar dalam Islam dibangun atas prinsipprisnip ar-ridhaa, persaingan sehat (fair competition), keterbukaan (transparency), serta keadilan (justice), kejujuran (honesty).

\section{B. Mekanisme pasar Dalam Islam}

Distorsi pasar yang sering terjadi dalam sebuah transaksi adalah tadlīs, gharar, maysir, ihtikar dan bay'najasy. Distorsi pasar ini sering dilakukan oleh para pelaku pasar untuk mencari keuntungan cepat atau di atas wajar dengan merugikan pihak lain. Distorsi ini menciptakan ketidakadilan dan ketidakseimbangan di pasar. Menguntungkan bagi satu pihak tetapi merugikan bagi pihak lain. Agar tercipta pasar yang Islami di pasar sekunder (Agustianto, 2020).

Di tinjau dari para pelaku pasar, tentu yang semua pihak yang terlibat dalam pasar mempunyai kepentingannya masing-masing. Setiap transaksi yang terjadi merupakan upaya dari pemenuhan kebutuhan masing-masing. Disinilah moralitas islami harus punya peranannya, dimana nilai-nilai islami akan membentuk arah, cara dan penyelesaian pemenuhan kebutuhan para pelaku pasar. Para pelaku pasar akan bertindak sesuai dengan kaidah nilai-nilai islam yang ada. Realisasi dari konsep syariah itu memiliki tiga ciri yang mendasar yaitu prinsip keadilan, menghindari kegiatan yang dilarang dan memperhatikan aspek 
kemanfaatan. Ketiga prinsip tersebut berorientasi pada terciptanya sistem ekonomi yang seimbang yaitu keseimbangan antara memaksimalkan keuntungan dan pemenuhan prinsip syariah yang menjadi hal mendasar dalam kegiatan pasar (Cakrawala, 2018).

\section{PEMBAHASAN}

\section{A. Kekuatan Pasar dan Keseimbangannya dalam Ekonomi Islam}

Permintaan merupakan salah satu elemen yang menggerakkan pasar, istilah yang digunakan oleh Ibnu Taimiyah untuk menunjukkan permintaan ini adalah keinginan. Keinginan yang muncul pada konsumen sesungguhnya merupakan sesuatu yang kompleks, dikatakan berasal dari Allah. Namun, pada dasarnya ada faktor-faktor yang mempengaruhi permintaan ini, yaitu: harga barang yang bersangkutan, pendapatan konsumen, harga barang lain yang terkait, selera konsumen, ekspektasi (pengharapan), maslahah (tujuan dalam mengonsumsi barang). Permintaan ini juga tergambar dari kurva yang menunjukkan hubungan antara harga dan jumlah barang yang diminta.

Defenisi ini menurut Ibnu Taimiyah adalah kekuatan penting dalam pasar sebagai ketersediaan barang yang ada di pasar. Menurutnya penawaran bisa dari impor dan produksi lokal sehingga kegiatan ini dilakukan oleh produsen maupun penjual. Dalam pencapaian maslahah penawaran sendiri dibutuhkan keimanan yang ada pada diri produsen, apabila jumlah maslahah yang terkandung dalam barang yang diproduksi maka akan meningkatkan jumlah produksinya. Selain itu sebagai faktor dari penawaran sendiri tercermin dari keuntungan yang didapat dan yang menjadi unsur dari keuntungan ini adalah harga barang dan biaya produksi. Harga barang ini mempunyai pengaruh kepada nilai keadilan, sebab dengan harga yang tidak adil akan menurunkan penawaran di pasar yang akan berdampak buruk pada mekanisme pasar. Sedangkan untuk biaya produksi yang menyesuaikan harga merupakan hal yang wajar terjadi apabila mengalami kenaikan dengan penilai situasi dan kondisi yang ada.

Dalam beberapa kondisi, diperlukan adanya intervensi negara. Intervensi Negara menurut Islam dalam bidang Ekonomi Islam membolehkan campur tangan negara dalam kegiatan ekonomi. Karena, jika kegiatan ekonomi hanya mengandalkan mekanisme pasar saja dapat beresiko fatal untuk kemasalahatan umum. Kelemahan mekanisme pasar yaitu pasar selalu berpihak kepada yang kuat, baik dari segi capital, ilmu pengetahuan, teknologi maupun manajemen.

Selain itu, persoalan-persoalan ekonomi tidak bisa dilakukan hanya oleh mekanisme pasar saja, tetapi juga dapat melalui mekanisme non pasar. Sebagaimana telah diterapkan dalam sejarah, pemerinta islam pada masalalu tidak perna lepas dari peran dan intervensi Negara terhadap aktivitas bisnis 
masyarakat. Semua dijalankan untuk mencapai tujuan bisnis Islam serta untuk menghindarkan dari praktek-praktek kebatilan dalam masyarakat.

Landasan intervensi Negara terhadap prekonomian mengacu pada firman Allah SWT sebagai berikut: "Hai orang-orang yang beriman, taatilah allah dan taatilah rosul, dan ulil amri diantara kamu. Kemudian jika kamu berlainan pendapat tentang sesuatu, maka kembalikanlah ia kepada Allah dan Rasul, jika kamu benar-benar beriman kepada Allah dan hari kemudian. Yang demikian itu lebih utama bagimu dan lebih baik akibatnya". Peran Negara yang paling utama yang berkaitan dengan politik ekonomi. politik ekonomi adalah campur tangan pemerintah dalam proses ekonomi. Pemerintah tidak boleh menerima begitu saja hasil proses ekonomi melainkan pemerintah juga harus berusaha untuk mengadakan perubahan-perubahan tertentu.

Negara atau pemerintah merupakan faktor positif dalam prekonomian. Negara sangat berperan dalam pemenuhan dalam kebutuhankebutuhan pokok masyarakat secara menyeluruh, berikut kemungkinan pemenuhan kebutuhan sekunder dan tersiernya sesuai dengan kadar kesanggupannya. Dalam hal ini peran Negara bukan hanya bertujuan untuk meningkatkan taraf kehidupan dalam sebuah Negara semata, tanpa terjamin tidak nya tiap orang untuk menikmati kehidupan tersebut. Fungsi inilah yang akan diperankan Negara dengan seperangkat kebijakan nya. Ditegaskan oleh ibn Taimiyah, Negara berperan dalam menekankan masalah pengurangan kemiskinan, regulasi harga, kebijakan moneter dan menyusun perencanaan ekonomi.

Dalam ilmu ekonomi, keseimbangan pasar (market equilibrium) terjadi ketika orang bersedia untuk membeli (permintaan) sama dengan jumlah orang yang bersedia untuk menjual (penawaran) pada harga tertentu (Mishkin, 2008).

1. Keseimbangan Pasar Barang: Kurva IS

Pasar barang merupakan pasar dimana semua barang dan jasa yang diproduksi oleh suatu negara dalam jangka waktu tertentu. Pendekatan grafis digunakan untuk menggambarkan ekuilibrium di pasar barang. 


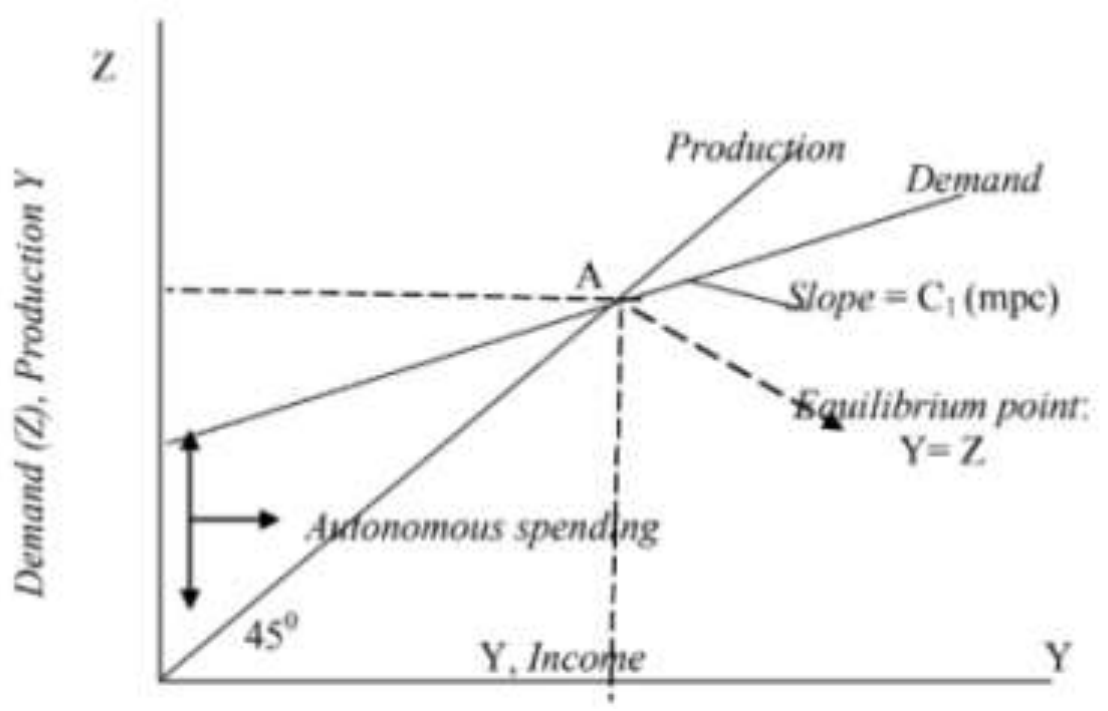

Gambar 1. Keseimbangan Pasar Barang

Dari keseimbangan di pasar barang ini dapat diturunkan kurva IS. Pada bagian ini, IS bukan lagi sesuatu yang autonomous melainkan dipengaruhi oleh tingkat bunga dan pendapatan. Jika, diasumsikan terjadi kenaikan tingkat bunga, maka hal ini akan berpengaruh terhadap besaran investasi. Kenaikan suku bunga akan mengakibatkan investasi turun. Karena, dengan naiknya suku bunga, maka untuk melakukan investasi disyaratkan tingkat pengembalian yang lebih tinggi agar biaya bunga pinjaman tertutupi. Selain itu, masyarakat lebih memilih untuk menyimpan uangnya dibank, yang relatif tinggi, dan tidak beresiko (Mishkin, 2008).

2. Keseimbangan Pasar Uang: Kurva LM

Kurva LM adalah kurva yang menghubungkan tingkat pendapatan nasional pada berbagai kemungkinan tingkat Bungan yang memelihara keseimbangan pasar uang (Hasyim, 2016).
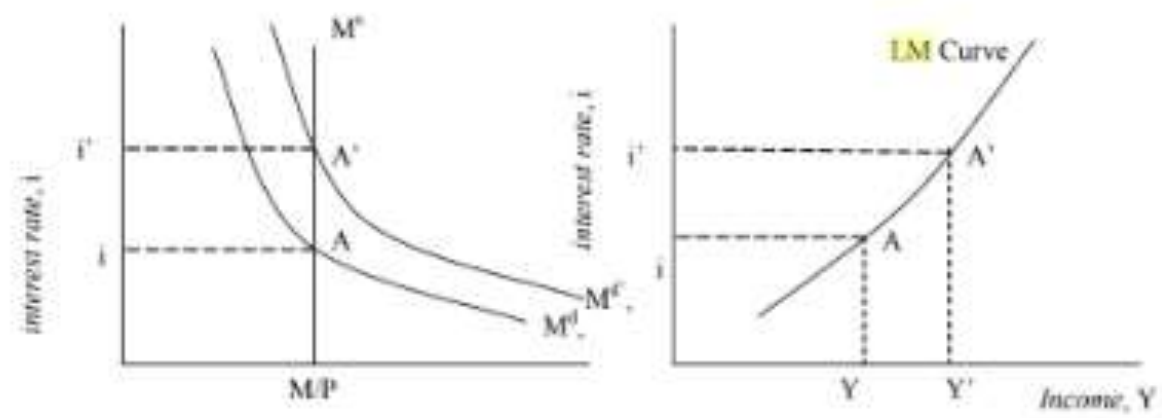

Real money MP

Gambar 2. Proses Penurunan Kurva LM

Proses penurunan keseimbangan pada pasar uang (LM). Kondisi awal terdapat keseimbangan antara money demand dengan money supply pada titik A dengan suku bunga sebesar I dengan pendapatan sebesar Y. Kemudian 
dimisalkan pendapatan naik dari $\mathrm{Y}$ ke $\mathrm{Y}^{\prime}$, maka akan menyebabkan money demand meningkat sehingga akan menggeser kurva $\mathrm{M}^{\mathrm{d}}$ menjadi $\mathrm{M}^{\mathrm{d}^{\prime}}$ yang berdampak pada kenaikan tingkat suku bunga dari i menjadi i' sehingga terbentuk keseimbangan baru dari A menjadi A' (Huda, 2012).

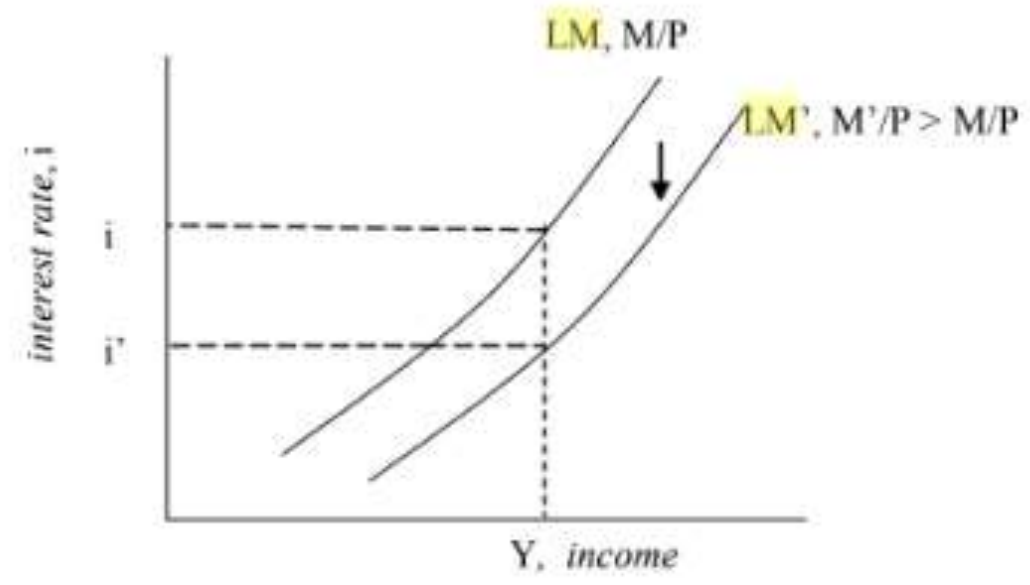

Gambar 3. Pergeseran Kurva LM

Kebijakan moneter dengan menambah atau mengurangi jumlah uang beredar akan mengakibatkan pergeseran kurva LM. Jika bank sentral menambah jumlah uang beredar, maka kurva LM akan bergeser kebawah, sebaliknya jika jumlah uang beredar dikurangi, maka kurva LM akan bergeser ke kiri atas.

3. Keseimbangan Pasar Barang dan Pasar Uang: Kurva IS-LM

Pemahaman efektivitas kebijakan moneter dapat dianalisis dengan kerangka dasar IS-LM atau keseimbangan di pasar barang dan pasar uang.

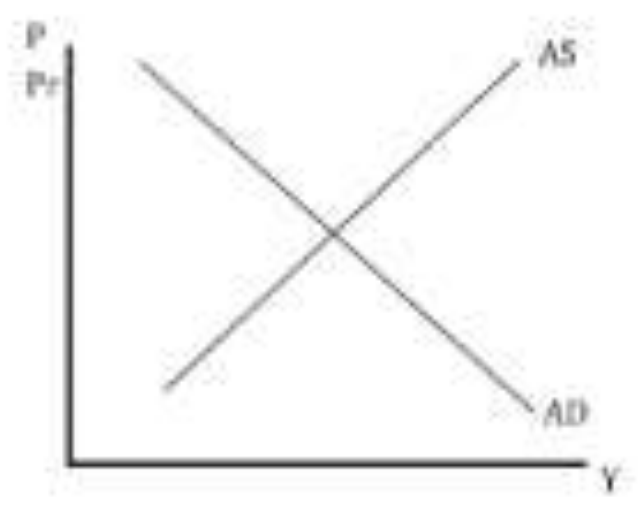

Kurva diatas menjelaskan koneksi antara permintaan aggrerat dan penawarannya, dimana keduanya dipertemukan dalam titik keseimbangan harga dan output tertentu. Jika, permintaan aggrerat meningkat, maka keseimbangan harga dan output akan bergeser kekanan. Namun, jika 
penawaran aggrerat yang meningkat akan mendorong harga turun namun terjadi peningkatan pada output.

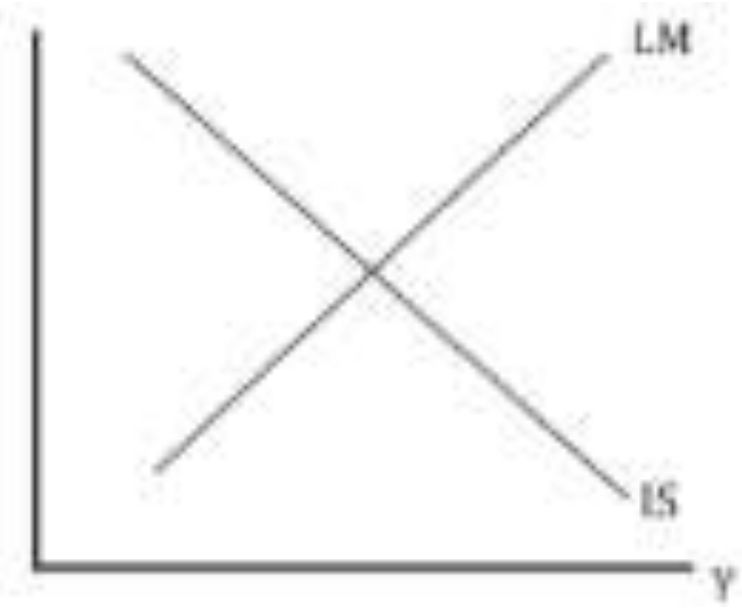

Pembentukan kurva permintaan aggrerat $(A D)$ secara umum dibentuk oleh keseimbangan pasar uang (LM) dengan pasar barang (IS), dimana titik keseimbangan keduanya akan bertemu pada tingkat suku bunga $(r)$ dan output keseimbangannya (Y). Secara umum, jika IS atau LM bergerak kekanan, maka kurva permintaan aggrerat (AD) pada akhirnya akan bergeser kekanan, begitu juga sebalinya.

Kajian mengenai pasar barang dan pasar uang ini mestinya masuk menjadi bagian dari kajian makroekonomi yang islami. Namun, ada hal-hal yang menjadikannya tidak sesuai atau bertentangan dengan nilai-nilai islam terutama jika dikaitkan dengan keberadaan faktor bunga yang memainkan variable penting dikedua pasar tersebut. Meski demikian, bahasan mengenai konsep IS-LM dalam konteks konvensional dan mnegakomodir sejumlah pemikiran yang mencoba membawa kajian tentang pasar uang dan barang ini dalam sebuah analisis yang Islami.

\section{B. Uang dan Fiskal dalam Perspektif Islam}

Menurut Metwally ada dua motif utama seorang muslim dalam memegang uang yaitu: Motivasi transaksi dan Motivasi berjaga-jaga. Dengan dua motif ini jelas, bahwa permintaan uang untuk tujuan spekulasi, tidak akan ada dalam ekonomi islam. Menurut Metwally juga dipengaruhi oleh tingkat pendapatan dan pengeluaran.

Motivasi berjaga-jaga meskipun dibenarkan namun tidak berlebihan atau hanya dibenarkan dengan jumlah yang terbatas. Terbatasnya jumlah uang untuk berjaga-jaga ini tidak terlepas dari kepercayaan seorang muslim akan janji Allah di Al-Qur'an, bahwa Allah akan menjamin rezeki mereka. Persamaan keseimbangan di pasar uang adalah sebagai berikut: 


$$
\mathrm{kY}-\mathrm{h}^{\prime} \mathrm{a}=\frac{M}{P}
$$

Keseimbangan di pasar uang ini dibangun berdasarkan asumsi jumlah uang beredar dan tingkat harga yang tetap, sehingga jumlahuang riil yang beredar pun tetap. Selanjutnya, berdasarkan persamaan diatas, dengan analisis matematis secara sederhana dapat diturnkan hubungan antara a dan $\mathrm{Y}$, yaitu:

$$
\alpha=\frac{1}{h^{\prime}}\left(k Y-\frac{M}{P}\right)
$$

Berdasarkan hubungan ini terlihat bahwa antara a atau bagi hasil dengan tingkat pendapatan terdapat suatu hubungan yang positif. Secara grafis, hubungan positif antara a dan $\mathrm{Y}$ ini akan digambarkan dalam suatu kurva yang disebut dengan Kurva LAM, yaitu:

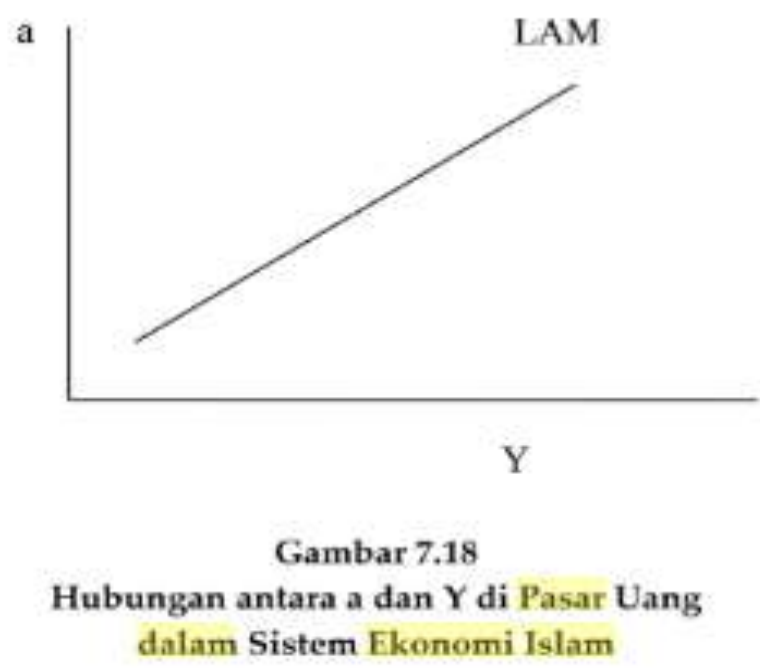

Gambar 4. Hubungan antara a dan Y di Pasar Uang dalam sistem Ekonomi Islam

Kebijakan fiscal dalam islam adlah sebuah sarana untuk mencapai maqhasidh syari'ah. Yang bertujuan untuk menciptakan masyarakat yang didasarkan pada keseimbangan distribusi kekayaan dengan menempatkan nilainilai material dan spiritual secara seimbang (Metwally: 1996). Bisa dikatakan, kebijakan fiscal memiliki peran penting dalam sistem ekonomi islam, bila dibandingkan dengan kebijakan moneter. Adanya larangan tentang riba dan kewajiban tentang pengeluaran zakat menyiratkan tentang pentingnya kedudukan kebijakan fiskal disbanding kebijakan moneter. Larangan bunga yang diberlakukan pada tahun Hijriah keempat telah mengakibatkan sistem ekonomi islam yang dilakukan oleh Nabi terutama berstandar pada kebijakan fiskalnya saja (Huda, 2012).

Sejarah Islam mencacat bagaimana perkembangan peran kebijakan fiskal dalam sistem ekonomi Islam mulai dari zaman awal Islam sampai kepada puncak kejayaan Islam pada zaman pertengahan. Setelah zaman pertengahan, seiring 
dengan kemunduran dalam pemerintah Islam yang ada pada waktu itu, maka kebijakan fiskal islami tersebut sedikit demi sedikit digantikan dengan kebijakan fiskal lainnya dari sistem ekonomi yang sekarang kita kenal dengan nama sistem ekonomi konvensional.

Dalam praktiknya, diperlukan adanya sistem pengawasan yang menjamin keberlangsungan pasar secara adil. Sistem ekonomi Islam mengenl istilah hisbah. Hisbah adalah institusi negara yang pernah ada pada zaman Nabi Muhammad saw. sebagai lembaga pengawas pasar ekonomi yang menjamin tidak adanya pelanggaran aturan moral dalam pasar monopoli, juga terhadap hak konsumen, keamanan, dan kesehatan kehidupan ekonomi (Sasono, 1998). Sedangkan, orang yang bertugas melakukan pengawasan perdagangan (pengawasan pasar) disebut sebagai muhtasib (Romly, 2019). Orang-orang yang diangkat menjadi muhtasib haruslah orang-orang yang mempunyai kemampuan berijtihad dalam hukumhukum agama (Santoso, 2003). Tugas lembaga hisbah ini adalah memberi bantuan kepada orang-orang yang tidak dapat mengembalikan haknya tanpa bantuan dari petugas-petugas hisbah. Sedangkan, tujuan hisbah dalam kegitaan ekonomi adalah untuk mewujudkkan beberapa tujuan, yaitu: Memastikan dijalankannya aturan-aturan kegiatan ekonomi, mewujudkan keamanan dan ketentraman, mengawasi keadaan rakyat, melarang orang membuat aliran air tanpa adanya kebutuhan, menjaga kepentingan umum, mengatur transaksi di pasar (Malia, 2016).

Peran lembaga hisbah dalam perekonomian (bisnis) islam, yaitu: Standarisasi mutu yang cukup tinggi, regulasi perdagangan lebih teratur, terhindarnya ekonomi biaya tinggi, harga yang terbentuk di masyarakat tidak akan menzhalimi masyarakat, kesejahteraan masyarakat akan lebih merata, perdagangan di dunia international lebih menguntungkan.

\section{Distorsi Pasar: Bentuk dan Penanganannya}

Distorsi pasar dapat dihindari dan diatasi dengan langkah-langkah seperti melarang semua jenis distorsi pasar yang disengajaserta menghukum pelaku pasar yang melakukannya. Selain itu dapat dilakukan upaya membuka akses informasibagi semua pelaku pasar

Regulasi harga oleh pemerintah jika memang bena- benar dibutuhkan dan tidak ada cara lain untuk menghilangkan distorsi pasar tersebut.

1. Rekayasa Permintaan (Demand) dan Rekayasa Penawaran (Supply)

a. Ihtikar yaitu melakukan penimbunan barang dengan tujuan spekulasi, sehingga ia mendapatkan keuntungan besar di atas keuntungan normal atau dia menjual hanya sedikit barang untuk mendapatkan harga yang lebih tinggi, sehingga mendapatkan keuntungan di atas keuntungan normal. Ikhtikar sering kali diterjemahkan sebagai monopoli dan/atau 
penimbunan. Padahal sebenarnya ihtikar tidak identik dengan monopoli dan/atau penimbunan. Dalam Islam, siapa pun boleh berbisnis tanpa peduli apakah dia satu-satunya penjual (monopoli) atau ada penjual lain. Menyimpan stock barang untuk keperluan persediaan pun tidak dilarang dalam Islam. Jadi monopoli sah-sah saja. Demikian pula menyimpan persediaan. Yang dilarang adalah ihtikar, yaitu mengambil keuntungan di atas keuntungan normal dengan cara menjual lebih sedikit barang untuk harga yang lebih tinggi, atau istilah ekonominya monopoly's rent-seeking. Jadi dalam Islam, monopoli boleh. Sedangkan monopoly's rent seeking tidak boleh. Suatu kegiatan masuk dalam ketegori intikar apabila tiga unsur berikut terdapat dalam kegiatan tersebut:

1) Mengupayakan adanya kelangkaan barang baik dengan cara menimbun stock atau mengenakan entry barriers.

2) Menjual dengan harga yang lebih tinggi dibandingkan dengan harga sebelum munculnya kelangkaan

3) Mengambil keuntungan yang lebih tinggi dibandingkan keuntungan sebelum komponen 1 dan 2 dilakukan (Karim, 2003).

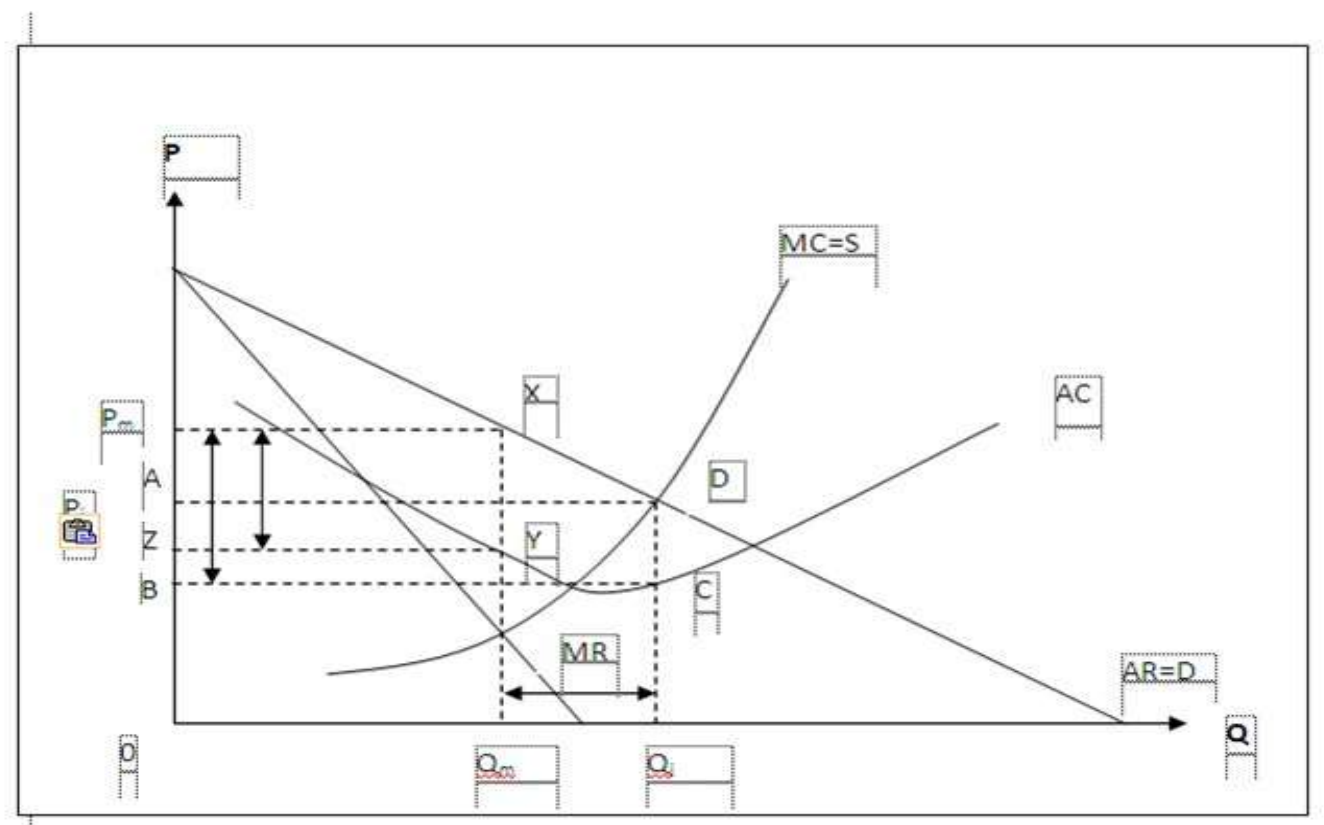

b. Bai' Najasy. Najsy adalah sebuah praktek dagang dimana seseorang purapura menawar barang yang didagangkan degan maksud hanya untuk menaikkan harga, agar orang lain bersedia membeli dengan harga itu, Ibnu 'Umar r.a. berkata: "Rasulullah SAW melarang keras praktek jual beli najsy".

Di dalam hadits yang diriwayatkan oleh Tirmidzi, Rasulullah SAW bersabda: 
"Janganlah kamu sekalian melakukan penawaran barang tanpa maksud untuk membeli". (HR.Tirmidzi)

Transaksi najasy diharamkan dalam perdagangan karena si penjual menyuruh orang lain memuji barangnya atau menawar dengan harga yang lebih tinggi, agar orang lain tertarik pula untuk membelinya. Si Penawar sendiri tidak bermaksud untuk benar-benar membeli barang tersebut. la hanya ingin menipu orang lain yang benar-benar ingin membeli yang sebelumnya orang ini telah melakukan kesepakatan dengan penjual. Akibatnya terjadi permintaan palsu (false demand). Tingkat permintaan yang terjadi tidak dihasilkan secara alamiyah (Amalia, 2013).

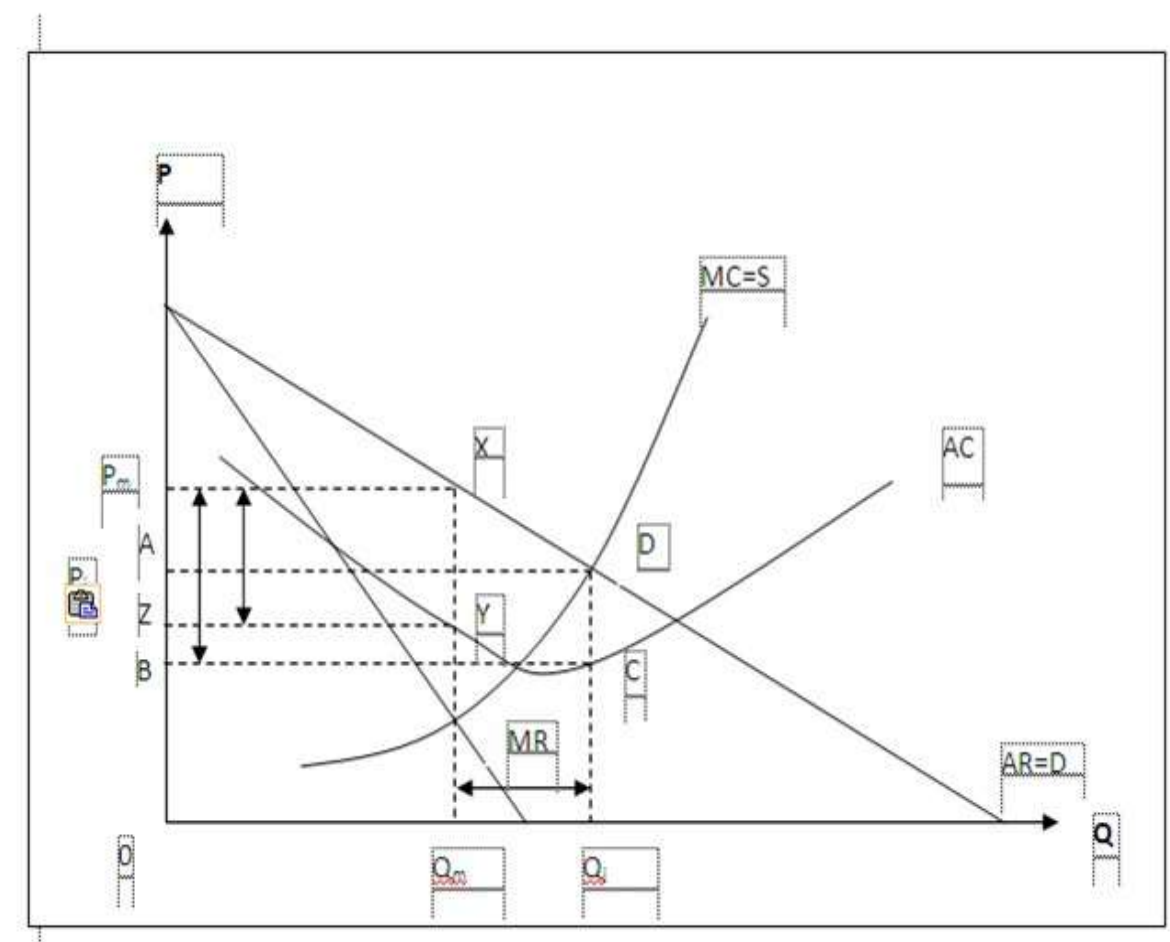


c. Talaqqi Rukban. Adalah tindakan yang dilakukan oleh pedagang kota membeli barang petani diluar kota untuk mendapatkan harga yang lebih murah dari harga pasar yang sesungguhnya. Rasulullah melarang ini dalam hadis yang diriwayatkan oleh Bukhari. Dalam Islam mencari barang dengan harga yang lebih murah tidaklah dilarang. Namun, apabila transaksi jual beli antara dua pihak, dimana yang satu pihak memiliki informasi yang lengkap dan yang satu pihak lagi tidak tahu berapa harga di pasar sesungguhnya dan kondisi demikian dimanfaatkan untuk mencari keuntungan yang lebih, maka terjadilah penzaliman oleh pedagang kota terhadap petani yang dari desa. Hal inilah yang dilarang, tindakan Talaqqi Rukhban ini tidak hanya menzalimi petani akan tetapi telah merusak keseimbangan pasar, sehingga pasar berada pada level yang lebih rendah

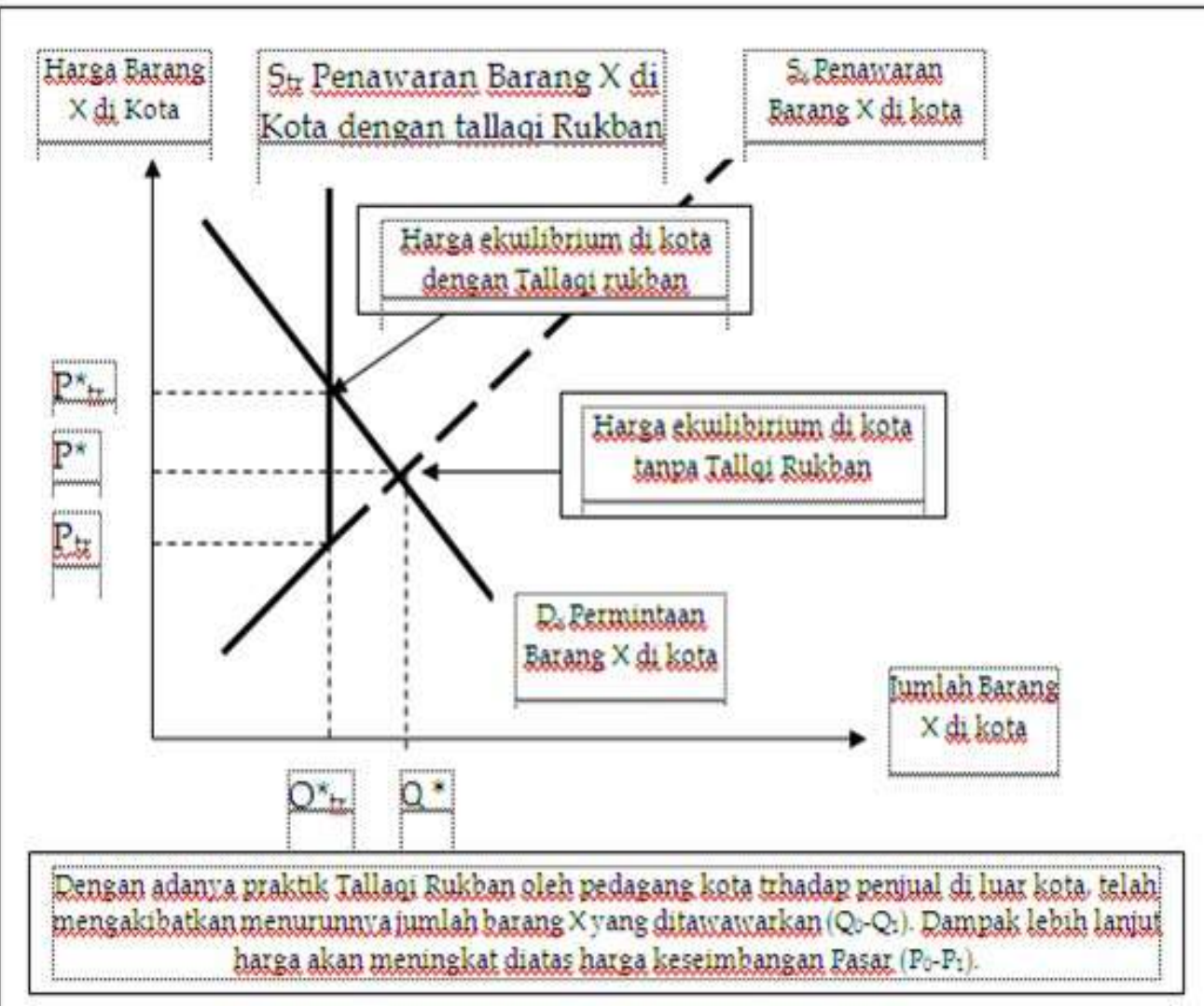

2. Penipuan (Tadlis) Tadlis adalah kondisi di mana satu pihak tidak mengetahui kondisi yang sebenarnya (unknown to one party) sehingga pihak yang mengetahui informasi memanfaat kondisi tersebut untuk mendapatkan keuntungan dengan menipu pihak yang tidak tahu. Kondisi ini disebabkan karena adanya incomplete information. Tadlis bisa terjadi dari segi kualitas, kuantitas, harga dan waktu penyerahan. Tadlis ini terjadi karena adanya 
ketidakjujuran di antara pihak yang melakukan transaksi (Karim, 2003). Sistem Ekonomi Islam melarang hal ini (ketimpangan informasi tentang barang yang akan diperjualbelikan) karena dengan adanya informasi yang tidak sama antara kedua belah pihak, maka unsur, 'an tarâdh minkum' (kerelaan bersama) dilanggar. Untuk menghindari penipuan, masing-masing pihak harus mempelajari strategi pihak lain. Dalam ekonomi konvensional, hal ini dikenal dengan zero some game theory. Contohnya mencampur beras kualitas baikdengam beras kualitas buruk dan dijual dengan harga beras kualitas baik (Nasution, 2006). Tadlis dibedakan mennjadi tiga, yaitu:

a. Tadlis dalam kuantitas ialah kegiatan menjual barang kuantitas sedikit dengan harga barang kuantitas banyak. Misalnya menjual baju sebanyak satu kontainer. Karena jumlah dan tidak mungkin untuk menghitung satu per satu, penjual berusaha melakukan penipuan dengan mengurangi jumlah barang yang dikirim kepada pembeli.

b. Tadlis dalam kualitas ialah menyembunyikan cacat atau kualitas barang yang buruk yang tidak sesuai dengan yang disepakati oleh penjual dan pembeli. Contoh tadlis dalam kualitas adalah pada pasar penjualan komputer bekas. Pedagang menjual komputer bekas dengan kualifikasi Pentium III dalam kondisi 80 \% baik, dengan harga Rp 3.000.000,00. Pada kenyataannya, tidak semua penjual menjual komputer bekas dengan kualifikasi yang sama.

c. Tadlis dalam harga ialah menjual barang dengan harga yang lebih tinggi atau lebih rendah dari harga pasar karena ketidaktahuan pembeli atau penjual. Dalam fiqih disebut ghaban.

d. Tadlis dalam waktu penyerahan ialah bila si penjual tahu persis ia tidak akan dapat menyerahkan barang pada besok hari, namun menjanjikan akan menyerahkan barang tersebut pada besok hari. Walau konsekuensi tadlis dalam waktu penyerahan tidak berkaitan secara langsung dengan harga ataupun jumlah barang yang ditransaksikan, namun masalah waktu adalah sesuatu yang sangat penting.

3. Taghrir berasal dari kata bahasa arab gharar, yang berarti akibat, bencana, bahaya, risik dan ketidakpastian. Dalam istilah fikih muamalah, taghrir berarti melakukan sesuatu secara membabi buta tanpa pengetahuan yang mencukupi, atau mengambil risiko sendiri dari suatu perbuatan yang mengandung risiko tanpa memikirkan konsekuensinya (Sophiandi, 2017). Jual beli gharar ialah suatu jual beli yang mengandung ketidak-jelasan atau ketidak pastian. Jual beli gharar dan tadlis sama-sama dilarang, karena keduanya mengandung incomplete information. Namun berbeda dengan tadlis, dimana incomplete informationnya hanya dialamin oleh satu pihak saja (unknown to one party), misalnya pembeli saja atau penjual saja, dalam gharar incomplete 
information dialami oleh dua pihak, baik pembeli maupun penjual. Jadi dalam gharar terjadi ketidakpastian (ketidakjelasan) yang melibatkan dua pihak (unknown to both parties). Contohnya jual beli ijon, jual beli anak sapi yang masih dalam kandungan induknya, menjual ikan yang ada di dalam kolam. sbagaimana tadlis, jual beli gharar juga terjadi pada empat hal, yaitu: kualitas, kuantitas, harga dan waktu.

a. Taghrir dalam kuantitas Contoh taghrir dalam kuantitas adalah sistem ijon. Misalnya petani sepakat untuk menjual hasil panennya (beras dengan kualitas kepada tengkulak dengan harga $\mathrm{Rp} 750.000,00$ padahal pada saat kesepakatan dilakukan, sawah si petani belum dapat dipanen. Dengan demikian, kesepakatan jual beli dilakukan tanpa menyebutkan spesifikasi mengenai berapa kuantitas yang dijual (berapa ton, berapa kuintal, misalnya) padahal harga sudah ditetapkan. Dengan demikian, terjadi ketidakpastian menyangkut kuantitas barang yang ditransaksikan.

b. Taghrir dalam kualitas Contoh taghrir dalam kualitas adalah menjual anak sapi yang masih dalam kandungan induknya. Penjual sepakat untuk menyerahkan anak sapi itu lahir, seharga Rp 1.000.000,00. Dalam hal ini, baik si penjual maupun si pembeli tidak dapat memastikan kondisi fisik anak sapi tersebut bila nanti sudah lahir. Apakah akan normal, cacat, atau lahir dalam keadaan mati. Dengan demikian, terjadi ketidakpastian menyangkut kualitas barang yang ditransaksikan.

c. Taghrir dalam harga misalnya seorang penjual menyatakan bahwa ia akan menjual satu unit panci merk $A B C$ seharga $R p$ 10.000,00 atau yang $R p$ $50.000,00$. Katakanlah ada pembeli yang membayar lunas pada bulan ke-3, berapa harga yang berlaku? Atau ekstremnya satu hari setelah penyerahan barang, berapa harga yang berlaku? Ekstrem lainnya bagaimana menentukan harga bila dibayar lunas sehari sebelum akhir bulan ke-5? Dalam kasus ini, walaupun kuantitas dan kualitas barang sudah ditentukan, tetapi terjadi ketidakpastian dalam harga barang karena si penjual dan si pembeli tidak mensepakati satu harga dalam satu akad.

d. Taghrir dalam waktu penyerahan Misalkan Adi kehilangan mobil VW beetlenya. Ida kebetulan sudah lama ingin memiliki mobil VW beetle seperti yang dimiliki oleh Adi, dan karena itu ia ingin membelinya. Akhirnya Adi dan Ida membuat kesepakatan. Adi menjual mobil VW beetle-nya yang hilang tersebut kepada Ida seharga Rp 100 juta. Harga pasar VW beetle adalah Rp 300 juta. Mobil akan diserahkan segera setelah ditemukan. Dalam transaksi ini terjadi ketidakpastian menyangkut waktu penyerahan barang, karena barang yang dijual tidak diketahui keberadaannya. Mungkin mobil tersebut akan ditemukan satu bulan lagi, satu tahun lagi, atau bahkan tidak akan ditemukan sama sekali (Gustiandi, 2015). 


\section{Peran Pemerintah}

Apabila terjadi kegagalan dalam pasar (distorsi pasar), maka pemerintah harus turun tangan. memastikan mekanisme pasar yang adil kembali bekerja. Menurut Islam negara memiliki hak untuk melakukan intervensi dalam kegiatan ekonomi baik itu dalam bentuk pengawasan, pengaturan maupun pelaksanaan kegiatan ekonomi yang tidak mampu dilaksanakan oleh masyarakat.Dalam konsep ekonomi islam, cara pengendalian harga ditentukan oleh penyebabnya. Bila penyebabnya adalah perubahan pada Genuine demand dan Genuine supply, Maka mekanisme pengendalian dilakukan melalui market intervention (kontrol harga). Sedangkan bila penyebabnya adalah distorsi Genuine demand dan Genuine supply, maka mekanisme pengendalian dilakukan melalui penghilangan distorsi termasuk penentuan price intervention untuk mengembalikan harga pada keadaan sebelum distorsi (Sumar'in, 2015).

Keterlibatan pemerintah dalam pasar hanyalah pada saat tertentu atau bersifat temporer. Sistem ekonomi Islam menganggap Islam sebagai sesuatu yang ada di pasar bersama-sama dengan unit-unit elektronik lainnya berdasarkan landasan yang tetap dan stabil. Dia dianggap sebagai perencana, pengawas, produsen, dan juga sebagai konsumen. Yang dimaksud "aturan-aturan permainan" ekonomi Islam adalah perangkat perintah dan aturan sosial, politik, agama, moral, dan hukum yang mengikat masyarakat. Lembaga-lembaga social disusun sedemikian rupa untuk mengarahkan individu-individu sehingga mereka secara baik melaksanakan aturan-aturan ini dan mengontrol serta mengawasi. Berlakunya aturan-aturan ini membentuk lingkungan di mana para individu melakukan kegiatan ekonomi. Aturan-aturan itu sendiri bersumber pada kerangka konseptual masyarakat dalam hubungan dengan, kekuatan tertinggi (Tuhan), kehidupan, sesama manusia, dunia, sesama makhluk, dan tujuan akhir manusia.

Hal pertama yang harus dilakukan pemerintah adalah perbaikan moral lewat pendidikan dan sosialisasi terhadap aturan yang diberlakukan secara maksimal. Mengingat Hukum juga merupakan alat rekayasa sosial, maka tugas ini dapat dilakukan bersamaan tetapi harus dipastikan terlebih dahulu bahwa norma yang yang dipositifkan bersumber dari al quran dan sunnah. Baru kemudian masalah penerapan sanksi diputuskan sehingga tidak melangkahi kewenangan syarak (Jabbar, 2017).

\section{SIMPULAN}

Pasar merupakan instrumen strategis dalam kehidupan dan aktivitas ekonomi. Diperlukan panduan dan prinsip yang tegas untuk menjamin keberlangsungan mekanisme pasar yang adil dan mensejahterakan masyarakat. Hal ini dengan ketentuan tegas yang diterapkan untuk menghindari berbagai 
macam bentuk distorsi pasar yang dapat merugikan masyarakat sebagai pelaku pasar. Berdasarkan hal tersebut, direkomendasikan kepada Pemerintah dan pelaku pengawasan pasar untuk tetap menjaga nilai-nilai keadilan dan kemaslahatan dalam berjalannya praktik jual beli di pasar, sehingga tidak ada pihak atau orang yang dirugikan satu sama lainnya.

\section{DAFTAR PUSTAKA}

Agustianto. (2020). Mekanisme Pasar dalam Perspektif Ekonomi Islam. Shariaeconomics.

https://shariaeconomics.wordpress.com/2011/02/26/mekanismepasardalam-perspektif-ekonomi-islam

Amalia, E. (2013). Mekanisme Pasar dan Kebijakan Penerapan Harga Adil dalam Perspektif Islam. Al-lqtishad: Journal of Islamic Economics, 5(1).

Cakrawala. (2018). Mekanisme Pasar. Jurnal Studi Islam, 13(2).

Ekomadani. (2015). Distorsi Pasar Dalam Pandangan Islam. Journal of Islamic Economic and Social, 1(1).

Gustiandi. (2015). Distorsi Pasar dalam Proses Transaksi Sekuritas Syariah di Pasar Sekunder. Etikonomi, 14(2).

Hasyim, A. I. (2016). Ekonomi Makro. Kencana.

Huda, N. (2012). Keuangan Publik Islami; Pendekatan Teoritis dan Sejarah. Jakarta Kencana.

Jabbar, J. (2017). Kewenangan Pemerintah Menerapkan Sanksi terhadap Pelaku Distorsi Pasar Berdasar Maqashid Syariah. Al-Manaahij: Jurnal Kajian Hukum Islam, 11(2).

Karim, A. A. (2003). Ekonomi Mikro Islami. Rajawali Press.

Malia. (2016). Implementasi Lembaga Hisbah dalam Meningkatkan Bisnis Islami. Jurnal Ekonomi Islam, 7(2).

Mishkin, F. S. (2008). Ekonomi, Uang, Perbankan, dan Pasar Keuangan. Salemba Empat.

Nasution, M. E. (2006). Pengenalan Eksklusif Ekonomi Islam. Kencana Prenada.

Rahardja, P., \& Manurung, M. (1999). Teori Ekonomi Mikro Suatu Pengantar. LPFEUI.

Romly. (2019). Al Hisbah al Islamiyah: Sistem Pengawasan Pasar dalam Islam. Deepublish.

Santoso, T. (2003). Membumikan Hukum Pidana Islam: Penegakan Syariat dalam Wacana dan Agenda. Gema Insani Press.

Sasono, A. (1998). Solusi Islam atas Problematika Umat. Gema Insani Press.

Sophiandi, E. (2017). Analisis Distorsi Pasar dalam Perspektif Islam. Kasaba: Journal of Islamic Economy, 10(1).

Sumar'in. (2015). Islam Sebuah Pendekatan Ekonomi Mikro Perspektif Islam. Graha Ilmu. 